\title{
KONSEP SYUKUR (GRATEFULNES) (Kajian Empiris Makna Syukur bagi Guru Pon-Pes Daarunnahdhah Thawalib Bangkinang Seberang, Kampar, Riau)
}

\author{
Akmal \\ Dosen Fakultas Tarbiyah UIN Sultan Syarif Kasim Riau \\ E-mail: akmal@uin-suska.ac.id \\ Masyhuri \\ Dosen Fakultas Psikologi UIN Sultan Syarif Kasim Riau \\ E-mail: masuri_ocu@yahoo.com
}

\section{Abstrak}

Kebersyukuran (gratitude) adalah respons positif yang ditunjukkan dalam menerima sesuatu dari orang lain atau pengalaman yang terjadi. Penelitian tentang kebersyukuran ini bertujuan untuk mengetahui bagaimana makna dan sumbersumber kebersyukuran bagi guru Pondok Pesantren Daarun Nahdhah Thawalib Bangkinang. Penelitian ini menggunakan pendekatan kualitatif dengan metode grounded theory. Subjek dalam penelitian ini adalah Guru Pon-Pes Daarunnahdhah Thawalib Bangkinang yang berjumlah 40 orang. Proses pengambilan data dilakukan dengan memberikan angket kepada partisipan dalam bentuk pertanyaan terbuka. Hasil penelitian menunjukkkan bahwa makna bersyukur bagi guru Pon-Pes Daarunnahdhah Thawalib Bangkinang adalah menerima segala pemberian nikmat dari Allah SWT dengan perasaan bahagia dan apa adanya dan dikuti dengan rasa terima kasih atas pemberian tersebut dengan mengucapkan alhamdulillah serta menjalankan segala perintahnya dan saling berbagi atas nikmat yang telah diberikan". Sumber kebersyukuran bagi guru Pon-Pes Daarunnahdhah Thawalib Bangkinang adalah Keluarga, harta, prestasi akademik, kesehatan, pengalaman hidup, umur, kemudahan dalam hidup dan ilmu pengetahuan. Adapun cara bersyukur bagi guru Guru Pon-Pes Daarunnahdhah Thawalib Bangkinang adalah dengan cara memuji Allah dengan mengucapkan Alhamdulillah, beribadah mendekatkan diri kepada Allah, bersedekah, berinfaq, sujud syukur dan menjaga Kepemilikan yang telah diberikan Allah.

\section{Kata Kunci: Konsep Syukur, Guru Pon-Pes Daarunnahdhah Thawalib}




\section{Abstract}

Gratitude is a positive response that is shown in accepting something from other people or experiences that occur. This research on gratitude aims to find out how the meaning and sources of gratitude for the Daarun Nahdhah Thawalib Islamic Boarding School teachers in Bangkinang. This study uses a qualitative approach with grounded theory. The subjects in this study were 40-person Pon-Pes Teacher Daarunnahdhah Thawalib Bangkinang. The process of data collection is done by giving questionnaires to participants in the form of open questions. The results of the study indicate that the meaning of gratitude for the Pon-Pes teacher Daarunnahdhah Thawalib Bangkinang is to accept all gifts of favor from Allah SWT with a feeling of happiness and what it is and followed by gratitude for the gift by saying alhamdulillah and carrying out all his orders and sharing the blessings has been given". The source of gratitude for Pon-Pes teachers Daarunnahdhah Thawalib Bangkinang is family, wealth, academic achievement, health, life experience, age, ease in life and science. The grateful way for the Pon-Pes teacher teacher Daarunnahdhah Thawalib Bangkinang is by praising Allah by saying Alhamdulillah, worshiping draws closer to Allah, gives charity, invests, prostrates gratitude and keeps the Ownership that God has given.

\section{Keywords: Syukur Concept, Pon-Pes Teacher Daarunnahdhah Thawalib}

\section{A. PENDAhUluan}

Seligman (2005) mengungkapkan bahwa syukur (gratitude) merupakan salah satu dari kajian psikologi positif tersebut, yang berarti mengucapkan terima kasih atas anugerah yang diberikan. Beberapa penelitian membuktikan keterkaitan yang erat antara rasa syukur dengan emosi positif lainnya. Penelitian Sheldon dan Sonja (2006) menunjukkan bahwa kebersyukuran dapat mengurangi emosi negatif pada diri seseorang. Penelitian Froh, Kashdan, dan Ozimkowski (2009) menemukan bahwa orang yang menuliskan surat 
terima kasih memiliki perasaan positif dan rasa syukur yang lebih besar. Penelitian Froh, Emmons, Card, Bono, dan Wilson, (2011) dan McCullough, Emmons, dan Tsang (2002) menemukan bahwa orang yang memiliki rasa syukur yang tinggi ternyata memiliki rasa iri hati dan depresi yang rendah.

Emosi-emosi positif yang muncul karena rasa syukur diantaranya adalah kemurahan hati kepada orang lain (McCullough, Kimeldorf, \& Cohen, 2008), perasaan optimis menjalani kehidupan (Hyland, Whalley, \& Geraghty, 2007), dan memiliki suasana hati yang lebih baik (McCullough, Tsang, \& Emmons, 2004; Sheldon \& Lyubomirsky, 2006). Kebersyukuran juga mengarahkan seseorang untuk memandang dirinya lebih positif. Penelitian Froh, Yurkewicz, dan Kashdan (2009) membuktikan bahwa rasa syukur memiliki hubungan yang kuat dengan penghargaan terhadap diri, pandangan hidup positif, dan inisiatif. Penelitian Wood, Joseph, dan Linley (2007) juga menemukan bahwa syukur berkorelasi positif dengan reinterpretasi positif, koping aktif, perencanaan hidup dan berkorelasi negatif dengan perilaku menyalahkan. Rasa syukur dapat meningkatkan perilaku prososial (Froh, dkk., 2009; Bartlett \& DeSteno, 2006; Algoe, Haidt, \& Gable, 2008; Froh, Bono, \& Emmons, 2010), merasa puas dengan pengalaman hidupnya (Froh, Sefick, \& Emmons, 2008; Chen \& Kee, 2008; Lambert, Fincham, Stillman, \& Dean, 2009), dan rasa syukur adalah prediktor kuat kesejahteraan seseorang (Watkin, Wood-ward, Stone, \& Kolt, 2003.

Syukur juga menjadi bagian dari ajaran Islam, yang tidak asing dan bahkan sudah "dipraktekkan" dalam kehidupan sehari-hari. Pengucapan "Alhamdulillah" sebagai simbol dari 
rasa kebersyukuran. Akan tetapi, syukur sesungguhnya tidak hanya cukup pada pengucapan tersebut, karena syukur berkaitan dengan lisan, hati dan anggota badan. Pemahaman mengenai syukur, khususnya pada masyarakat Indonesia yang beragama Islam tentunya diperoleh melalui ajaran- ajaran dalam Islam, yang juga dipengaruhi oleh budaya yang ada dalam Indonesia. Pribadi individu, tingkah laku dan lingkungan saling mempengaruhi satu sama lain dalam membentuk suatu perilaku atau kepribadian. Subandi (2005) menegaskan bahwa psikologi dan agama memiliki hubungan erat, agama dapat menjadi referensi dalam menafsirkan dan solusi permasalahan jiwa. Ajaran-ajaran agama yang dipelajari akan membentuk keyakinan yang menjadi bagian dari proses kognitif.

\section{B. PEMBAHASAN}

\section{Pengertian Syukur (Gratefulness)}

Syukur dalam psikologi positif dinamakan dengan Gratitude diambil dari bahasa latin, gratia yang merupakan bentuk dari grace (Rahmat), gratefulness (rasa bersukur) dan graciousness (Emmons, Mc.Cullough, \& Tsang, 2003). Ide Utamanya berhubungan dengan kindness (kebaikan hati), generousness (kedermawanan), gifts (hadiah), the beauty of giving and receiving (keindahan dalam memberi dan menerima). (Pruyser, 1976). Emmon mendefenisikan gratitude adalah respons positif yang ditunjukkan dalam menerima sesuatu dari orang lain atau pengalaman yang terjadi .contohnya seseorang yang mengalami peristiwa alam yang terjadi seperti dilanda badai, krisis kesehatan dan dapat menemukan manfaat atau hikmah dari pengalaman tersebut (Afflek\&tennen, 1996). Robert Emmon 
(2005) perasaan gratitude akan muncul apabila 1. Dianggap mahal bagi penerima, 2. Memiliki harga bagi penerima 3. sengaja diberikan. Dengan demikian, rasa syukur menyentuh kecenderungan untuk menghargai dan menikmati peristiwa dan pengalaman sehari-hari (Bryant, 1989; Langston, 1994).

Gratitude bisa dilihat sebagai konsep yang berharga dan bermakna bagi setiap agama hindu, budha, islam, Kristen dan yahudi (emmon, 2003). Thomas Aquinas (1981) tidak hanya gratitude yang memberikan manfaat terhadap perilaku akan tetapi juga dpengaruhi oleh kekuatan motivasi dari manusia. Perilaku Gratitude adalah mengakui tentang adanya sumber dari luar dirinya yang berperan dalam pengalamannya bersyukur. Oleh karena itu gratitude dapat mendorong seseorang untuk mengekspresikan ungkapan kebersyukurannya dengan mengucapkan pujian atau berterima kasih pada yang memberinya atau dengan menyalurkan kebaikan pada pihak lain. Menurut McCullough (2002) Gratitude terdiri dari empat fase yaitu:

a. Intensity, seseorang yang bersyukur ketika mengalami peristiwa positif diharapkan untuk merasa lebih intens bersyukur;

b. Frequency, seseorang yang me mliki kecenderungan bersyukur akan merasakan banyak perasaan bersyukur setiap harinya dan Gratitude bisa menimbulkan dan mendukung tindakan dan kebaikan sederhana atau kesopanan. 
c. Span, yaitu dari peristiwa kehidupan bisa membuat seseorang merasa Gratitude atas keluarga, pekerjaan, kesehatan, dll.

d. Density, adalah orang yang bersyukur diharapkan dapat menuliskan lebih banyak nama-nama orang yang telah dianggap membuatnya Gratitude, termasuk orang tua, keluarga, teman, dll.

\section{Memelihara Kebersyukuran (gratitude)}

Robert Emmons and Michael McCullough (2003) menggali beberapa cara untuk meningkatkan dan memelihara sikap kebersyukuran (gratitude) yaitu membuat jurnal diri tentang rasa bersyukur (gratitude journal ) setiap minggu dengan membuat catatan tentang perbandingan kejadian kondisi diri dalam kondisi netral maupun negative (life stresses). Jurnal Gratitude memberikan manfaat dalam hal (1) jumlah aktivitas yang dilakukan, (2) optimisme minggu mendatang, dan (3) merasa lebih baik tentang kehidupan. Journal gratitude ini terbukti secara significant dapat memelihara tujuan hidup, kesehatan, hubungan interpersonal, dan kemampuan akademik. Penelitian selanjutnya melalui diary condition dengan mengontrol kondisi gratitude (count blessing), hasil penelitian menunjukkan bahwa orang yang mengontrol gratitude melalui jurnal gratitude; 1. Lebih optimistis, 2. Lebih Energik, 3. Lebih bisa menjaga hubungan dengan orang lain, 4. Tidur lebih nyenyak.

Studi lain dengan menggunakan tekhnik meditasi dari jepang yang dikenal dengan Naiken dapat meningkatkan rasa kebersyukuran (gratitude) dengan cara meditasi setiap hari dengan memunculkan tiga pertanyaan; 
1. Apa yang saya terima, 2. Apa yang sudah saya berikan, 3. Permasalahan dan kesulitan apa yang saya berikan terhadap orang lain.

\section{Syukur dalam Pandangan Islam}

Kata Syukur dalam ensklopedi Islam yaitu asy-syukr yang artinya ucapan, perbuatan, dan sikap terima kasih atau al-hamdu yang berarti pujian. Sedangkan menurut istilah syara' syukur adalah pengakuan terhadap nikmat yang dikaruniakan Allah yang disertai dengan ketundukan kepadanya dan mempergunakan nikmat tersebut sesuai dengan kehendak Allah (Muhammad Syafi'I, 2009). Syukur dalam ilmu tasawuf berarti ucapan, sikap, dan perbuatan terima kasih kepada Allah SWT dan pengakuan yang tulus atas nikmat dan karunia yang diberikanNya.

M. Quraish Shihab (1996) mengungkapkan bahwa dalam Al-Quran kalimat syukur banyak disebutkan dalam ayat-ayat al-Qur'an sebanyak 64 kali. Sebagaimana dalam surat Ibrahim ayat 7 yang artinya, "Sesungguhnya jika kamu bersyukur, pasti kami akan menambah (kenikmatan)." Surat An-Nisa ayat 147, "Mengapa Allah akan menyiksamu, jika kamu bersyukur dan beriman?”, suart Ali-Imran ayat 145, "dan Kami akan memberi balasan kepada orang-orang yang bersyukur." Syukur merupakan hal wajib yang harus dilakukan manusia, karena syukur merupakan perintah Allah yang tersirat dalam surat Al-Baqarah ayat 152, "Bersyukurlah kepada-Ku dan janganlah kamu mengingkari nikmat- Ku." Ayat ini menunjukkan bahwa syukur sebagai wujud perintah kepada manusia untuk selalu mengingat Allah tanpa melupakan dan patuh kepadaNya tanpa menodai dengan kedurhakaan. 
Ibnu Qayyim Al-Jauziyah menggambarkan syukur dengan tiga makna yaitu, mengetahui nikmat yang artinya menghadirkan nikmat di dalam pikiran, mempersaksikan dan membedakannya. Kedua, dengan arti menerima nikmat dari Allah dengan segala kerendahan diri kepadaNya. Dan ketiga yaitu memuji karena nikmat yang berarti memuji Sang Pemberi, Allah SWT. Imam al-Qusyairi mengatakan,"hakikat syukur adalah pengakuan terhadap nikmat yang telah diberikan Allah yang di buktikan dengan ketundukan kepada-Nya. Jadi, syukur itu adalah mempergunakan nikmat Allah menurut kehendak Allah sebagai pemberi nikmat. Karena itu, dapat dikatakan bahwa syukur yang sebenarnya adalah mengungkapkan pujian kepada Allah dengan lisan, mengakui dengan hati akan nikmat Allah, dan mempergunakan nikmat itu sesuai dengan kehendak Allah.

Syaikh Abdul Qadir al-Jailani menyebutkan bahwa hakikat syukur adalah mengakui nikmat Allah karena Dialah pemilik karunia dan pemberian sehingga hati mengakui bahwa segala nikmat berasal dari Allah SWT. Kemudian anggota badannya tunduk kepada pemberi nikmat itu. Yang disebut tunduk adalah mentaati dan patuh karena seseorang tidak disebut tunduk, kecuali jika dia mentaati perintah Allah dan patuh kepada syari'at-Nya. Dengan demikian syukur merupakan pekerjaan hati dan anggota badan.

Al-Ghazali dalam kitab Ihya' Ulumuddin (2000) menjelaskan bahwa syukur tersusun atas tiga hal, yaitu ilmu, keadaan dan amal perbuatan. Pertama, Ilmu adalah mengenai pengetahuan tentang Sang Pemberi, sumber 
kenikmatan dan sifat-sifat yang menyertai-Nya. Kedua, keadaan merupakan adanya suatu rasa kegembiraan terhadap yang memberi nikmat dan disertai dengan sikap tunduk dan tawadhu', Ketiga amal perbuatan yaitu melaksanakan segala sesuatu yang dimaksud oleh Sang Pemberi, yang melibatkan hati, lisan dan anggota badan. Dengan hati berarti bermaksud untuk berbuat baik, dengan lisan dapat mengungkapkan rasa syukur dengan bertahmid (Alhamdulillah) yang bukan diniatkan untuk pamer. Adapun anggora badan yaitu dengan menggunakan segala kenikmatan untuk taat kepada Allah dengan menjauhi perbuatan yang dilarangNya dan melakukan segala perbuatan yang disukaiNya.

Dengan demikian, syukur diartikan Al-Ghazali yaitu menggunakan nikmat yang diperoleh pada segala hal yang disukai Allah. Untuk memahani yang dicintai Allah, perlu memahami bahwa Allah adalah yang menciptakan segala sesuatu yang ada di dunia, apapun bentuknya, baik suka maupun duka. Segala hal tersebut mengandung hikmah yang memiliki maksud, dan apabila manusia mampu menangkap maksud tersebut dengan baik maka, itulah yang dicintai-Nya. Barangsiapa yang memperhatikan diri dan melakukan intropeksi diri tentang segala sesuatu yang ada dalam dirinya, maka ia akan memperoleh nikmar yang banyak sebagaimana dengan iman, ilmu, waktu kosong, kesehatan, keamanan dan lain sebagainya. Rasulullah SAW juga bersabda:

"Barangsiapa mengenai dunia ia memandang kepada orang yang berada di bawahnya dan mengenai agama ia memandang kepada orang yang di atasnya, niscaya ia ditulis oleh Allah SWT sebagai orang yang sabar dan 
syukur. Dan barangsiapa mengenai dunia ia memandang kepada orang yang di atasnya dan mengenai agama memandang kepada orang yang di bawahnya, niscaya ia tidak ditulis oleh Allah sebagai orang yang sabar dan bersyukur." (HR. At-Tirmidzi)

Mengungkapkan rasa syukur tidak hanya kepada Sang Pemberi, Allah SWT, melainkan juga kepada manusia yang menjadi perantara kehadiran nikmat Allah. Terdapat salah satu riwayat yamengatakan bahwa barangsiapa yang tidak bersyukur kepada manusia, berarti ia tidak bersyukur kepada Allah. Hal ini dengan jelas menggambarkan bahwa orang yang bersyukur akan memiliki perilaku sosial yang baik. Tidak hanya pada sesuatu yang menyenangkan saja kita manusia hrus bersyukur, karena penderitaan dunia pun harus disyukuri. Ketika penderitaan dunia disyukuri maka, akan mendatangkan manfaat besar dan pahala melimpah, sehingga apabila dibandingkan dengan penggantinya tersebut maka penderitaan yang dialami tiada berarti.

Al-Ghazali (dalam Ensiklopedi Islam, 1994) cara bersyukur kepada Allah SWT, ada tiga cara, yaitu:

a. Bersyukur dengan hati, yaitu mengakui dan menyadari sepenuhnya bahwa segala nikmat yang diperoleh berasal dari Allah,SWT dan tidak seorangpun yang dapat memberikan nikmat itu melainkan allah SWT.

b. Bersyukur dengan lidah, yaitu mengucapkan secara jelas ungkapan rasa syukur itu dengan kalimat Alhamdulillah.

c. Bersyukur dengan amal perbuatan yaitu mengamalkan anggota tubu untuk hal-hal yang baik dan 
memanfaatkan nikmat tersebut sesuai dengan ajaran agama.

Sejalan dengan Al-Ghazali, Syaikh Abdul Qadir alJailani juga menjelaskan tentang cara bersyukur sebagai berikut, bersyukur dengan lisan adalah lisan mengakui bahwa nikmat itu berasal dari Allah dan tidak menyandarkannya kepada makhluk atau kepada dirimu sendiri, daya mu, kekuatanmu, atau usahamu. Syukur dengan hati adalah dengan keyakinan yang abadi, kuat, dan kokoh bahwa semua nikmat, manfaat, dan kelezatan yang ada padamu, baik lahir maupun batin, gerakanmu maupun diammu adalah berasal dari Allah bukan dari selain-Nya, dan kesyukuranmu dengan lisanmu merupakan ungkapan dari apa yang ada di dalam hatimu. Sedangkan bersyukur dengan anggota badan adalah hendaknya kamu menggerakkan dan menggunakannya untuk ketaatan kepada Allah bukan untuk selainnya dari makhluk.

\section{Metode Penelitian}

a. Pendekatan Penelitian

Penelitian ini menggunakan pendekatan kualitatif dengan metode grounded theory. Metode grounded theory merupakan seperangkat strategi induktif untuk mengumpulkan dan menganalisis data kualitatif. Tahapan metode meliputi beberapa pedoman induktif yang sistematis dalam bentuk pengumpulan, sintesis, analisis, dan konseptualisasi terhadap data kualitatif, dengan tujuan membangun teori (Charmaz, 2009). 
b. Subjek Penelitian

Subjek dalam penelitian ini adalah Guru Pon-Pes Daarunnahdhah Thawalib Bangkinang. Proses pengambilan data dilakukan dengan memberikan angket kepada partisipan dalam bentuk pertanyaan terbuka, yaitu:

1) Apa makna syukur menurut Bapak/Ibu?

2) Coba sebutkan pengalaman yang membuat Bapak/Ibu merasa bersyukur?

3) Bagaimana cara Bapak/Ibu mengungkapkan rasa bersyukur?

c. Tekhnik Analisis Data

Tekhnk analisis data dalam penelitian ini menggunakan tekhnik coding yang terdiri dari tiga tahapan yaitu:

1) open coding, yaitu mengidentifikasi kategori-kategori tema yang muncul;

2) Kedua, axial coding, yaitu melihat hubunganhubungan antara kategori yang satu dengan kategori yang lain;

3) Ketiga, selective coding, yaitu menyeleksi kategori yang paling mendasar, kemudian secara sistematis menghubungkannya dengan kategori-kategori lain dan memvalidasi hubungan tersebut (Poerwandari, 2005). Berdasarkan hubungan antar kategori tersebut dan dihubungkan dengan dua pertanyaan dalam angket, kemudian akan ditemukan rumusan konstruk syukur yang dicari. 


\section{Hasil Penelitian}

a. Deskripsi Responden Penelitian

Jumlah responden berdasarkan jenis kelamin, usia dan pendidikan terakhir adalah sebagai berikut.

Tabel 1. Responden Berdasarkan Jenis Kelamin

\begin{tabular}{|l|c|c|}
\hline Jenis Kelamin & Frekuensi & Persen \\
\hline Laki-laki & 23 & $57,5 \%$ \\
\hline Perempuan & 17 & $42,5 \%$ \\
\hline Jumlah & $\mathbf{4 0}$ & $\mathbf{1 0 0} \%$ \\
\hline
\end{tabular}

Pada tabel 1 terlihat bagaimana komposisi responden berdasarkan jenis kelamin didominasi oleh perempuan. Responden perempuan berjumlah 23 orang $(57,5 \%)$, sedangkan responden laki-laki berjumlah 17 orang (42,5\%). Ketidakseimbangan antara jumlah responden perempuan dan laki-laki merupakan sebuah konsekuensi dari penelitian indigenos yang menghendaki data yang didapatkan secara natural tanpa adanya kontrol terhadap komposisi responden (Jamaluddin \& Lufityanto 2017).

Tabel 2. Usia Responden

\begin{tabular}{|c|c|c|}
\hline Usia Minimal & Usia Maksimal & Rata-rata \\
\hline 23 Tahun & 47 Tahun & 30 Tahun \\
\hline
\end{tabular}

Tabel 2 memberikan informasi mengenai komposisi usia responden, terlihat bahwa usia responden yang paling muda adalah 23 tahun dan usia responden yang paling tua adalah 47 Tahun. Sementara itu rata-rata usia responden berada dalam rentan usia 30 tahun. Oleh karena itu dapat disimpulkan bahwa responden dalam penelitian ini telah melalui masa dewasa awal yaitu rentan usia di atas 18 tahun.Menurut Hood (dalam 
Chizanah dan Hadjam, 2011)seseorang dalam usia dewasa awal telah memiliki kesadaran akan komitmen beragama serta mencerminkan kemandirian dan tanggung jawab.

Tabel 3. Pendidikan Terakhir Responden

\begin{tabular}{|l|c|c|}
\hline Jenjang Pendidikan & Frekuensi & Persen \\
\hline S1 & 32 & $80 \%$ \\
\hline S2 & 6 & $15 \%$ \\
\hline SLTA & 1 & $2,5 \%$ \\
\hline Tidak Mencantumkan & 1 & $2,5 \%$ \\
\hline Jumlah & $\mathbf{4 0}$ & $\mathbf{1 0 0} \%$ \\
\hline
\end{tabular}

Pada tabel 3 terlihat bagaimana komposisi responden berdasarkan pendidikan terakhir didominasi oleh responden yang berpendidikan S1. Responden yang berpendidikan S1 berjumlah 32 orang (80\%), sedangkan Responden yang berpendidikan S2 berjumlah 6 orang (15\%), Responden yang berpendidikan SLTA berjumlah 1 orang $(2,5 \%)$ serta terdapat satu responden yang tidak mencantumkan pendidikaan terakhirnya di dalam kuesioner penelitian.

b. Hasil Penelitian

1) Makna bersyukur

Pada bagian ini, peneliti akan memaparkan hasil kategorisasi dari makna bersyukur bagi guru Guru PonPes Daarunnahdhah Thawalib Bangkinang. Makna bersyukur bagi guru Guru Pon-Pes Daarunnahdhah Thawalib Bangkinang didapatkan melalui pertanyaan "Apa makna bersyukur menurut Bapak/Ibu?. Adapun hasil kategorisasi dari pertanyaan ini dapat di lihat pada tabel 4 . 
Tabel 4. Makna Bersyukur

\begin{tabular}{|l|c|c|}
\hline Tema & Frekuensi & Persen \\
\hline Menerima & 19 & $47,5 \%$ \\
\hline Berterima Kasih & 16 & $40 \%$ \\
\hline Merasa Cukup & 3 & $7,5 \%$ \\
\hline Menikmati & 2 & $5 \%$ \\
\hline Jumlah & $\mathbf{4 0}$ & $\mathbf{1 0 0} \%$ \\
\hline
\end{tabular}

Pada tabel 4 terlihat bahwa makna bersyukur bagi guru Guru Pon-Pes Daarunnahdhah Thawalib Bangkinang adalah "Menerima segala pemberian nikmat dari Allah SWT dengan perasaan bahagia dan apa adanya dan dikuti dengan rasa terima kasih atas pemberian tersebut dengan mengucapkan alhamdulillah serta menjalankan segala perintahnya dan saling berbagi atas nikmat yang telah diberikan".

Adapun rincian dari tema-tema makna bersyukur bagi guru Guru Pon-Pes Daarunnahdhah Thawalib Bangkinang adalah sebagai berikut:

a) Menerima

"bersyukur adalah menerima segala sesuatu yang diberikan Allah" (R 04).

"menerima segala ketentuan Allah swt” (R 24).

"bisa menerima apa adanya dengan keadaan dan kondisi tanpa menyerah" (R32).

b) Berterima Kasih

"bersyukur itu berterimakasih atas nikmat yang telah dikasih oleh Allah" (R 11).

"bersyukur adalah ucapan terimakasih seorang hamba kepada Allah swt atas nikmat yang sudah didapatkan, yang diterapkan dalam bentuk ketaatan kepadaNya” (R 14). 
"syukur adalah rasa terima kasih yang dalam kepada yang kuasa" (R 33)

c) Merasa cukup (Qona'ah) "merasa qonaah, dan mengaplikasikan nikmat dan rahmat yag diberikan allah" ( $R$ O9). “merasa cukup" (R 31).

d) Menikmati "bersyukur menurut saya adalah menikmati segala keadaan yang diberian oleh allah dalam hidup saya. Baik keadaan tersebut yang saya inginkan maupun tidak. Saaat allah memberikan hal yang saya inginkan maka saya bersyukur agar allah menambah nikmat tersebut \& menjauhkan saya dari sifat kufur, disaat allah memberikan hal yang tidak saya inginkan maka saya pun bersyukut karena saya yakin ada sesuatu yang lebih indah yang telah dipersiapkan oleh Allah untuk saya” (R 08).

"menikmati apa yang kita dapat" (R 28).

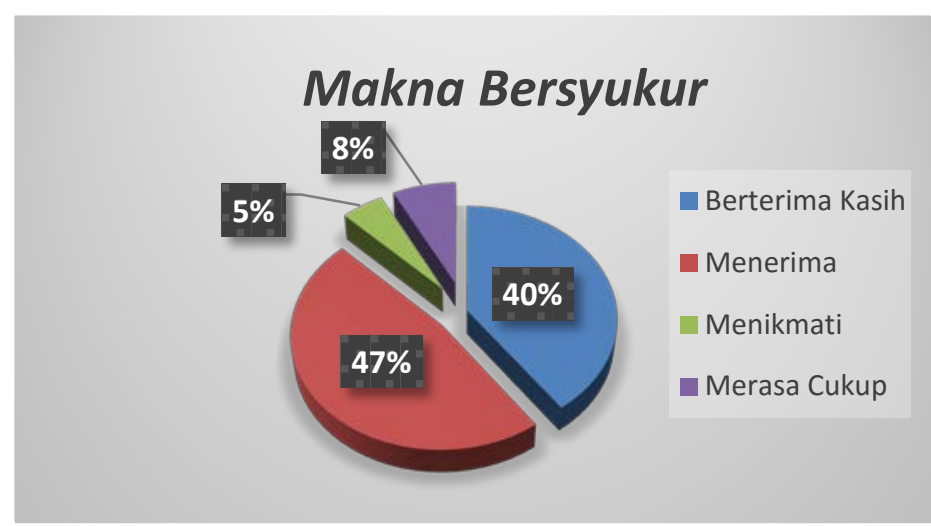

2) Sumber Rasa Syukur

Pada bagian ini, peneliti akan memaparkan hasil kategorisasi dari sumber rasa syukur bagi guru Guru Pon-Pes Daarunnahdhah Thawalib Bangkinang Sumber 
rasa syukur bagi guru Guru Pon-Pes Daarunnahdhah Thawalib Bangkinang didapatkan melalui pertanyaan "Sebutkan 2 (dua) pengalaman yang membuat Bapak/bu merasa paling bersyukur!".Pada pertanyaan ini peneliti meminta responden untuk memberikan 2 pengalaman yang membuat responden merasa bersyukur, dengan demikian nantinya jumlah pengalaman syukur yang akan dianalisis menjadi dua kali lipat jumlah responden (40 responden) yaitu 80 pengalaman. Adapun hasil kategorisasi dari pertanyaan ini dapat di lihat pada tabel 5

Tabel 5. Sumber Rasa Syukur

\begin{tabular}{lcc}
\hline Tema & Frekuensi & Persen \\
\hline Keluarga & 19 & $23.75 \%$ \\
Mendapatkan Rezeki & 18 & $22.5 \%$ \\
Pencapaian Akademik & 18 & $22.5 \%$ \\
Kesehatan & 5 & $6.25 \%$ \\
Pengalaman Hidup & 4 & $5 \%$ \\
Keyakinan Beragama & 4 & $5 \%$ \\
Umur & 4 & $5 \%$ \\
Kemudahan dalam Hidup & 3 & $3.75 \%$ \\
Ilmu & 2 & $2.5 \%$ \\
Keselamatan & 1 & $1.25 \%$ \\
(Tidak Menjawab) & 2 & $2.5 \%$ \\
\hline Jumlah Respon & $\mathbf{8 0}$ & $\mathbf{1 0 0} \%$ \\
\hline
\end{tabular}

Pada tabel 5 terlihat bahwa sumber rasa syukur bagi guru Guru Pon-Pes Daarunnahdhah Thawalib Bangkinang adalah sebagai berikut:
a) Keluarga
b) Mendapatkan Rezeki
c) Pencapaian Akademik
d) Kesehatan 

e) Pengalaman Hidup
f) Keyakinan Beragam
g) Umur
h) Kemudahan dalam Hidup
i) Ilmu
j) Keselamatan

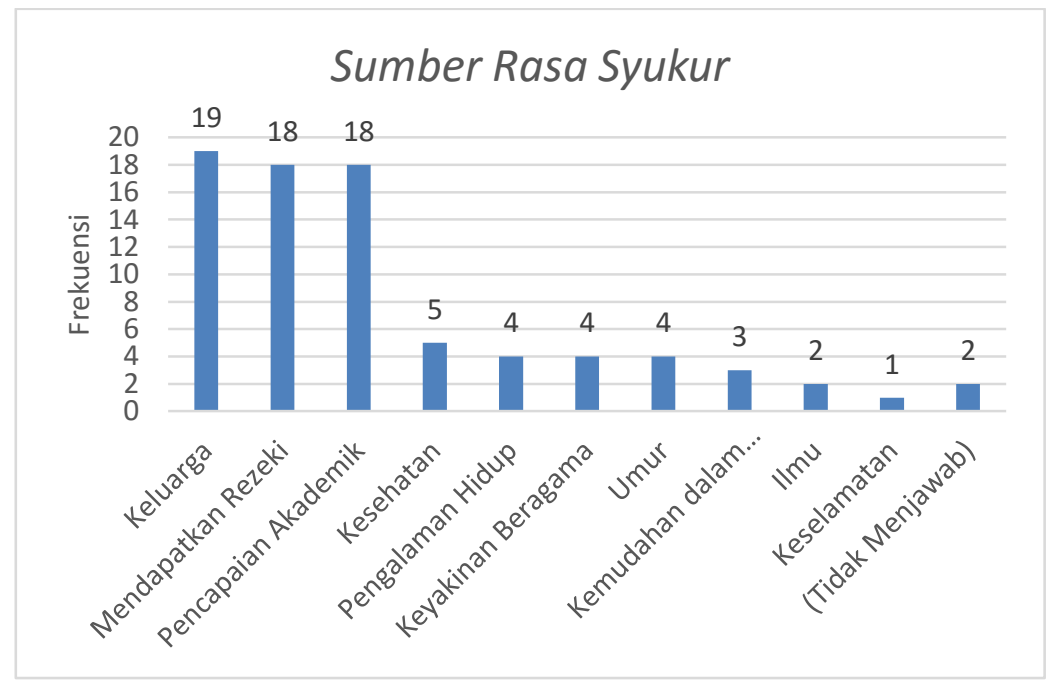

3) Cara Bersyukur

Pada bagian ini, peneliti akan memaparkan hasil kategorisasi dari cara bersyukur yang dilakukan oleh guru Guru Pon-Pes Daarunnahdhah Thawalib Bangkinang . Cara bersyukur yang dilakukan oleh guru Guru Pon-Pes Daarunnahdhah Thawalib Bangkinang didapatkan melalui pertanyaan "Bagaimana cara Bapak/Ibu mengungkapkan rasa bersyukur?”. Adapun hasil kategorisasi dari pertanyaan ini dapat di lihat pada tabel 6 . 
Tabel 6. Cara Bersyukur

\begin{tabular}{lcc}
\hline Tema & Frekuensi & Persen \\
\hline Memuji Allah & 18 & 45 \\
Mendekatkan Diri kepada Allah & 10 & 25 \\
Bersedekah & 5 & 12.5 \\
Beribadah & 2 & 5 \\
Berinfaq & 2 & 5 \\
Sujud Syukur & 2 & 5 \\
Menjaga Kepemilikan & 1 & 2.5 \\
\hline Jumlah & $\mathbf{2 0 3}$ & $\mathbf{1 0 0 \%}$ \\
\hline
\end{tabular}

Pada tabel 6 terlihat bahwa cara bersyukur bagi guru Guru Pon-Pes Daarunnahdhah Thawalib Bangkinang. Adapun rincian dari tema-tema cara bersyukur bagi guru Guru Pon-Pes Daarunnahdhah Thawalib Bangkinang adalah sebagai berikut:

a) Memuji Allah

b) Mendekatkan Diri kepada Allah

c) Bersedekah

d) Beribadah

e) Berinfaq

f) Sujud Syukar

g) Menjaga Kepemilikan

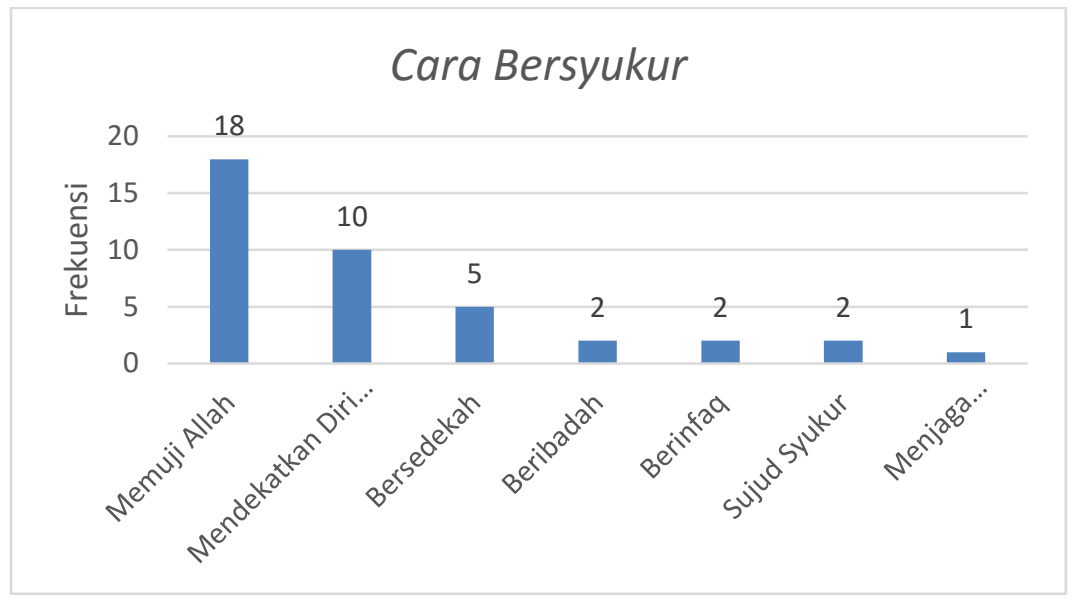




\section{KESIMPULAN}

Berdasarkan hasil analisis data di atas maka dapat ditarik kesimpulan bahwa makna bersyukur dalam penelitian ini adalah "Menerima segala pemberian nikmat dari Allah SWT dengan perasaan bahagia dan apa adanya dan dikuti dengan rasa terima kasih atas pemberian tersebut dengan mengucapkan alhamdulillah serta menjalankan segala perintahnya dan saling berbagi atas nikmat yang telah diberikan". Makna syukur dalam penelitian ini sejalan dengan makna syukur yang dikemukan oleh para ahli bahwa hakikat syukur adalah mengakui nikmat Allah karena Dialah pemilik karunia dan pemberian sehingga hati mengakui bahwa segala nikmat berasal dari Allah SWT.

Adapun rincian dari sumber rasa syukur bagi guru PonPes Daarunnahdhah Thawalib Bangkinang adalah keluarga, rezeki atau harta, pencapaian prestasi akademik, Kesehatan, pengalaman hidup, umur, kemudahan dalam hidup dan ilmu pengetahuan Adapun cara bersyukur bagi guru Guru Pon-Pes Daarunnahdhah Thawalib Bangkinang adalah : memuji Allah, beribadah dengan mendekatkan diri kepada Allah, Bersedekah, berinfaq, melakukan sujud syukur dan menjaga kepemilikan yang telah diberikan Allah. 


\section{DAFTAR PUSTAKA}

Al Jawziyyah, I.Q. From Islamic Psychology: Patience and gratitude. London: Ta-Ha Publisher.United Kingdom, 1997

Al-Jauziyah, I.Q Madarijus-Salikin: Jalan Menuju Allah, terj Katsur Suhardi, Jakarta: Pustaka Al-Kautsar, 1998

Atabik Ali dan Ahmad Z. M., Kamus Kontemporer ArabIndonesia, Yogyakarta: Multi Karya Grafika, 2003.

C.R. Snyder. Shane J.Lopez. Jennifer Terramoto, Positive Psychology: the Science and Practical Exploration Of Human Strength, Sage Publication, UK. 2011

Dewan Redaksi Ensiklopedi Islam, Ensiklopedi Islam Jilid 5, Pen.PT. Ikhtiar Baru van Hoeve, Jakarta, 1994

Emmons, R.A. The Psychology of gratitude: An introduction. Dalam Emmons, R.A. \&McCullough, M.E. The psychology of gratitude. NY: Oxford University Press. 2004

Giacomo Bono \& M. E. McCullough, Positive Responses to Benefit and Harm: Bringing Forgiveness and Gratitude into Cognitive Psychoterapy. Journal of Cognitive Psychoterapy: An Internasional Quarterly, Vol.20 No.2, 2006

Imam Al-Ghazali, Ihya' Ulumudiin, diterjemahkan oleh Mohammad Zuhri, dkk, Semarang: CV Asy-Syifa, 2000

Imam Al-Ghazali, Minhajul Abidin, terj Abul Hiyadl, Surabaya: Mutiara Ilmu, 1995.

Imam Al-Ghazali, Bahaya Penyakit Hati, terj Kholilah Marhijanto, Surabaya: Tiga Dua, 1994.

Martin E.P. Seligman, Authentic Happiness: Menciptakan Kebahagiaan dengan PsikologiPositif, Bandung: PT Mizan Pustaka, 2005.

M. K. Sheldon \& Lyubomirsky Sonja, "How To Increase And Sustain Posi-tive Emotion: The Effects Of Expressing Gratitude And $V$ isualizing Best Possible Selves", The Journal of Positif Psychology, April 2006, 
M. E. McCullough, R. A. Emmons dan Jo-Ann Tsang, The Grateful Dispo- sition: A Conceptual and Empirical Topography. Journal of personality and Social Psychology. Vol. 82. No. 1, 2002, hlm. 112-127

Mohammad Khodayarifard, Positive psychology from Islamic perspective, International Journal Behavior Sciience, 2016; 10(2): $77-83$

M. Q. Shihab, Wawasan Al-Qur 'an: Tafsir Maudlui Atas Pelbagai Persoalan Umat, Bandung: Mizan, 1996

Muhammad Syafi'ie el-Bantanie, Dahsyatnya Syukur, Jakarta: Qultum Media, 2009.

Robert A. Emmons and Robin Stern, Gratitude as a Psychotherapeutic Intervention, Journal of Clinical Psychology: In Session, August 2013.

R. A. Emmons dan M. E. McCullough, "Counting Blessing Versus Burdens: An experimental Investigation of Gratitude and Subjective Well-Being in Daily Life", Journal of Personality and Social Psychology, Vol.84 No. 2, 2003, hlm.377

R. A. Emmons, Michael E. McCullough, dan Jo-Ann Tsang, Positive Psy- chological Assasment, A Handbook of Models and Measures; The Assasment of Gratitude, Washington: American Psychological Assosiation, 2006.

Subandi, Reposisi Psikologi Islam, Makalah disampaikan pada temu Ilmiah Nasional 1 Psikologi Islam, Yogjakarta, 24 September 2005

Poerwandari, E.K. Pendekatan Kualitatif dalam Penelitian Psikologi. Jakarta: LPSP3 UI. 2005

W.J.S. Poerwadarminta, Kamus Umum Bahasa Indonesai, Pen. Balai Pustaka, Edisi ketiga, cet. IV, Jakarta, 2007 